\title{
Antagonistic Activity of Antibiotic Producing Streptomyces sp. against Fish and Human Pathogenic Bacteria
}

\author{
Md. Nazmul Hossain ${ }^{1}$ and Md. Mahbubur Rahman ${ }^{2 *}$ \\ ${ }^{I}$ Department of Genetic Engineering and Biotechnology; Shahjalal University of Science and Technology; Sylhet - \\ Bangladesh. ${ }^{2}$ Department of Biotechnology; Bangabandhu Sheikh Mujibur Rahman Agricultural University; \\ Gazipur - Bangladesh
}

\begin{abstract}
In this study, attempts were made to isolate Streptomyces sp. from soil samples of two different regions of Bangladesh and evaluate their antagonistic activity against fish and human pathogenic bacteria. A total of 10 isolates were identified as Streptomyces sp. based on several morphological, physiological and biochemical tests. Cross streak method was used to observe the antagonistic activity of the Streptomyces sp. isolates against different fish pathogens belonging to the genus Aeromonas, Pseudomonas and Edwardsiella and human clinical isolates belonging to the genus Klebsiella, Salmonella and Streptococcus. Seven Streptomyces sp. isolates showed antagonism against both fish and human pathogenic bacteria. Four isolates viz., N24, N26, N28 and N47 showed broad spectrum of antagonistic activity (80-100\%) against all genera of fish and human pathogenic bacteria. The isolate N49 exhibited highest spectrum of antagonism against all fish pathogens (90-100\%) but comparatively lower degree of antagonism against human pathogens (50-60\%). Rest of the two isolates (N21 and N23) showed variability in their antagonism. Results showed that broad spectrum antibiotic(s) could be developed from the isolates N24, N26, N28 and N47against several human and fish pathogens. The isolate N49 could be a potential source of antibiotic, especially for fish pathogenic bacteria.
\end{abstract}

Key words: Streptomyces sp., antagonistic activity, cross streak method, antibiotic

\section{INTRODUCTION}

Streptomyces are Gram-positive soil microbes represented as the largest number of species and varieties among the family Actinomycetaceae. Streptomyces species are the source of thousands of bioactive compounds and screening programs have shown that secondary metabolites can be isolated (Wendisch and Kutzner 1992; Santos 2012), which bind to active sites of enzyme organelles and receptors (William et al. 1983). Streptomyces sp. is responsible for the production $50 \%$ of clinically useful antibiotics (Miyadoh 1993).
Soil is a natural reservoir for the microorganisms with their antimicrobial products and provides an excellent resource for the isolation and identification of therapeutically important products (Dancer 2004). Among the soil microbes, Streptomyces sp. are the important group producing antibiotics of agricultural and medicinal importance and over 6,000 compounds have been reported to be produced by Streptomyces (Takahashi and Omura 2003; Kavitha et al. 2010). However, with the alarming increasing rate of drug resistance in pathogenic microorganisms throughout the world, the demand to discover newer and safer antibiotics with lesser side effects

*Author for correspondence: mahbub_biotech@yahoo.com 
are increasing day-by-day (Gupte et al. 2002). But, the search for a new, safer, broad-spectrum antibiotic with greater potency has been progressing slowly. The present work was undertaken with an effort to isolate antibiotic producing Streptomyces from two different soil samples of Bangladesh and evaluate their antagonistic potentials against some fish and human pathogenic bacteria.

\section{MATERIALS AND METHODS}

\section{Collection of soil samples}

Soil samples were collected from two different regions of Bangladesh during June to August 2011. Samples were taken up from a depth of 10 $\mathrm{cm}$ form each area, placed in sterile plastic bags, transported to the laboratory under ambient condition and air-dried at room temperature. The samples were pretreated by drying at $70^{\circ} \mathrm{C}$ for $1 \mathrm{~h}$ in a hot air dryer.

\section{Isolation of and enumeration of microbes from soil}

For isolation of Streptomyces sp., serial dilution technique was followed using different aqueous dilutions $\left(10^{-1}\right.$ to $\left.10^{-4}\right)$. Each diluted sample was inoculated by standard spread plate method on Starch-Casein Agar (SCA) medium containing (g/l) Glycerol 10, Casein 0.3, $\mathrm{KNO}_{3} 2.0, \mathrm{~K}_{2} \mathrm{HPO}_{4}$ 2.0, $\mathrm{MgSO}_{4}$ 0.05, $\mathrm{CaCO}_{3} 0.02, \mathrm{FeSO}_{4}$ 0.01, Agar 18 and distilled water $1 \mathrm{~L}(\mathrm{pH} 7.0 \pm 0.1)$ (Kuster and Williams 1964). After incubation of the plates at $30^{\circ} \mathrm{C}$ for seven days, typical Streptomyces sp. colonies were selected (Shirling and Gottlieb 1966) and total number of bacteria as well as total number Streptomyces colonies (presumptive colonies) were counted and expressed as colony forming unit per gram of soil sample (CFU/g). The selected colonies were re-streaked on Streptomyces Agar Medium (SAM) containing (g/l) Glucose 10, Beef extract 4.0, Peptone 4.0, $\mathrm{NaCl} 2.5$, Yeast extract 1.0 and Agar 20 (Atlas 1997) and incubated at $30^{\circ} \mathrm{C}$ to obtain the pure culture.

\section{Identification of Streptomyces sp. isolates}

Ten presumptive Streptomyces sp. isolates were characterized by morphological and physiological tests, which included colony characteristics (size, shape and color), Gram staining, presence of aerial mycelium, motility and spore formation, and biochemical tests, which included oxidase and catalase activity, $\mathrm{H}_{2} \mathrm{~S}$ production, Methyl Red test
(MR), Voges-Proskauer Test (VP), acid production from carbohydrates (glucose, lactose and sucrose), Indole test, hydrolysis of casein and starch, utilization of different carbon and nitrogen sources. The bacterial isolates were identified following the Bergey's Manual of Determinative Bacteriology (Bergey and John 1994).

\section{Test microorganisms}

Both fish pathogenic bacteria (viz., Aeromonas sp., Pseudomonas sp. and Edwardsiella sp.) and human clinical isolates (viz., Klebsiella sp., Salmonella sp. and Streptococcus sp.) were used as test organism to determine the antagonistic activity of the Streptomyces sp. isolates. Ten isolates from each bacterial genus were used to evaluate the antagonistic activity of the Streptomyces sp. isolates. All of the test isolates were obtained from the USDA project laboratory of the Department of Genetic Engineering and Biotechnology, Shahjalal University of Science and Technology, Sylhet, Bangladesh. The test organisms were cultured in Nutrient Broth (NB) at 27 and $37^{\circ} \mathrm{C}$ for $24 \mathrm{~h}$ for fish and human pathogens, respectively.

Evaluation of antagonistic activity of Streptomyces sp. Isolates

The antagonistic activity of soil isolates was evaluated by Cross Streak method (Rahman et al. 2011). Each of the isolate was streaked on Streptomyces Agar Medium (SAM) as straight line and incubated at $30^{\circ} \mathrm{C}$ for six days. Then the plates were seeded with test organisms by a single streak at a $90^{\circ}$ angle to the Streptomyces isolates and incubated at 37 and $27^{\circ} \mathrm{C}$ for $24 \mathrm{~h}$ for human and fish pathogenic bacteria, respectively. The antagonistic effect of Streptomyces sp. isolates on test organism was analyzed by the determination of size of inhibition zone. The percentage of antagonism of Streptomyces isolates to each genus of test organisms was estimated.

\section{RESULTS AND DISCUSSION}

\section{Isolation and enumeration of microbes from soil}

The colony forming unit (CFU) per gram of soil was estimated to know total bacterial load and load of presumptive Streptomyces sp. in different soil sample. The highest microbial count and Streptomyces count was $3.1 \times 10^{6} \mathrm{CFU} / \mathrm{g}$ of soil and $2.8 \times 10^{4} \mathrm{CFU} / \mathrm{g}$ of soil, respectively in the pond sediment sample of Sylhet region. The lowest 
bacterial count was $0.8 \times 10^{6} \mathrm{CFU} / \mathrm{g}$ of soil in the soil sample collected from the hill of Sylhet (Table 1). In the present study, the highest load of Streptomyces sp. was obtained in the pond sediment sample of Sylhet region of Bangladesh. This pond was used for fish farming and was rich in organic compounds that might be the reason for highest count of Streptomyces sp.

Table 1 - Soil samples with their total bacterial count and Streptomyces count.

\begin{tabular}{llll}
\hline Origin of soil sample & Nature of soil sample & $\begin{array}{l}\text { Total bacterial } \\
\text { count (CFU/g of soil) }\end{array}$ & $\begin{array}{l}\text { Total Streptomyces } \\
\text { count (CFU/g of soil) }\end{array}$ \\
\hline Agricultural land of Joypurhat & Water logged & $1.8 \times 10^{6}$ & $0.7 \times 10^{4}$ \\
Pond sediment of Joypurhat & Mud & $2.3 \times 10^{6}$ & $1.9 \times 10^{4}$ \\
Pond sediment of Sylhet & Mud & $3.1 \times 10^{6}$ & $2.8 \times 10^{4}$ \\
Hill of Sylhet & Sandy & $0.8 \times 10^{6}$ & $1.4 \times 10^{4}$ \\
Hill of Sylhet & Red- dry soil & $2.1 \times 10^{6}$ & $1.1 \times 10^{4}$ \\
\hline
\end{tabular}

\section{Identification of Streptomyces sp. isolates}

Baesd on the morphological, physiological and biochemical characteristics, all the isolates were identified as Streptomyces sp. All the isolates were Gram positive with aerial mycelium and most of them were filamentous with long chain of spores (Fig. 1A). The isolates were non-motile, catalase positive, oxidase positive, ureaese positive and positive for $\mathrm{H}_{2} \mathrm{~S}$ production, but negative for nitrate reduction, MR test and VP test. Detailed results of morphological, physiological and biochemical tests of the isolates are shown in Tables 2 and 3. Similar methods were followed by Shirling and Gottlieb (1966); Berd (1973) and Rahman et al. (2011) for the identification of Streptomyces sp. from soil.

Table 2 - Morphological and physiological properties of Streptomyces sp. isolates.

\begin{tabular}{|c|c|c|c|c|c|c|c|c|c|}
\hline \multirow{2}{*}{$\begin{array}{l}\text { Isolates } \\
\text { name }\end{array}$} & \multicolumn{3}{|c|}{ Colony characteristics } & \multirow{2}{*}{$\begin{array}{c}\text { Gram } \\
\text { staining }\end{array}$} & \multirow{2}{*}{$\begin{array}{c}\text { Aerial } \\
\text { mycelium }\end{array}$} & \multirow{2}{*}{ Filament } & \multirow{2}{*}{ Spore } & \multirow{2}{*}{ Motility } & \multirow{2}{*}{$\begin{array}{r}\text { Growth at } \\
30^{0}-37^{0}\end{array}$} \\
\hline & Color & Size & Shape & & & & & & \\
\hline N21 & Off-white & Small & Round & $\mathrm{G}+$ & + & + & + & - & + \\
\hline $\mathrm{N} 23$ & Off-white & Medium & Round & $\mathrm{G}+$ & + & + & + & - & + \\
\hline N24 & Brown & Medium & Round & $\mathrm{G}+$ & + & + & - & - & + \\
\hline N26 & Dark- brown & Small & Round & $\mathrm{G}+$ & + & + & + & - & + \\
\hline $\mathrm{N} 28$ & Off-white & Large & Round & $\mathrm{G}+$ & + & + & + & - & + \\
\hline N32 & Yellow & Small & Round & $\mathrm{G}+$ & + & + & + & - & + \\
\hline N33 & Brown & Medium & Round & $\mathrm{G}+$ & + & + & - & - & + \\
\hline N36 & Off-white & Medium & Round & $\mathrm{G}+$ & + & + & + & - & + \\
\hline N47 & Orange & Large & Round & $\mathrm{G}+$ & + & + & + & - & + \\
\hline N49 & Yellow & Medium & Round & $\mathrm{G}+$ & + & + & + & - & + \\
\hline
\end{tabular}

G+ = Gram positive, $+=$ Positive/ Present, $-=$ Negative/ Absent

Table 3 - Biochemical characteristics of Streptomyces sp. isolates.

\begin{tabular}{lc}
\hline Tests Performed & Results \\
\hline Melanin pigment & $\mathrm{D}$ \\
Catalase & + \\
Oxidase & + \\
Urease & + \\
$\mathrm{H}_{2}$ S production & + \\
Nitrate Reduction & - \\
Methyl Red (MR) & - \\
Voges-Proskaur (VP) & - \\
Citrate utilization & + \\
Hydrolysis of & \\
$\quad$ Casein & + \\
$\quad$ Starch & $\mathrm{D}$ \\
Lipid & + \\
Utilization of carbon source & \\
$\quad$ D-glucose & + \\
D-manitol & + \\
$\quad$ Fructose & + \\
Sucrose & $\mathrm{D}$ \\
Utilization of Nitrogen source & \\
D-alanine & + \\
L-arginine & + \\
L-tyrosine & + \\
\hline$+=$ positive reaction, - = negative reaction, & $\mathrm{D}=$ different isolates \\
gave different reaction. &
\end{tabular}

Antagonistic activity of Streptomyces sp. isolates Among the ten Streptomyces sp. isolates, seven showed antagonistic activity against different fish pathogenic and human clinical isolates in cross streak method used in this study (Fig. 1B). Cross streak method is relatively easy and reliable method, especially for the screening program to test the antagonistic activity of antibiotic producing microbes, which is commonly used (Lemos et al. 1985; Ceylan et al. 2008; Arifuzzaman et al. 2010; Rahman et al. 2011; Valli et al. 2012). Determination of antagonism against different microorganisms is very important to determine the spectrum of antibiotic produced by an isolate. Here, the percentage of antagonism against different fish and human pathogenic bacteria were evaluated to measure the spectrum of antibiotic produced by the soil isolates. Similar type of study was also conducted by others 
(George et al. 2010). In this study, four of the seven antagonistic isolates viz., N24, N26, N28 and N47 showed broad spectrum of antagonistic activity (80-100\%) against the test isolates belonging to all bacterial genera. The isolate N49 exhibited highest spectrum of antagonism against all fish pathogens (90-100\%) but comparatively lower degree of antagonism against human pathogens (50-60\%). Hence, the isolate N49 could be considered as a valuable source for the development of antibiotic against fish disease caused by Aeromonas sp., Pseudomonas sp. and Edwardsiella sp. The other two isolates N21 and N23 showed variability in their antagonism but maximum to fish pathogenic Pseudomonas sp. (80\%) and Edwardsiella sp. (70\%), respectively. The antagonistic activity of Streptomyces sp. isolates to different fish and human pathogenic bacteria has given in Table 4.
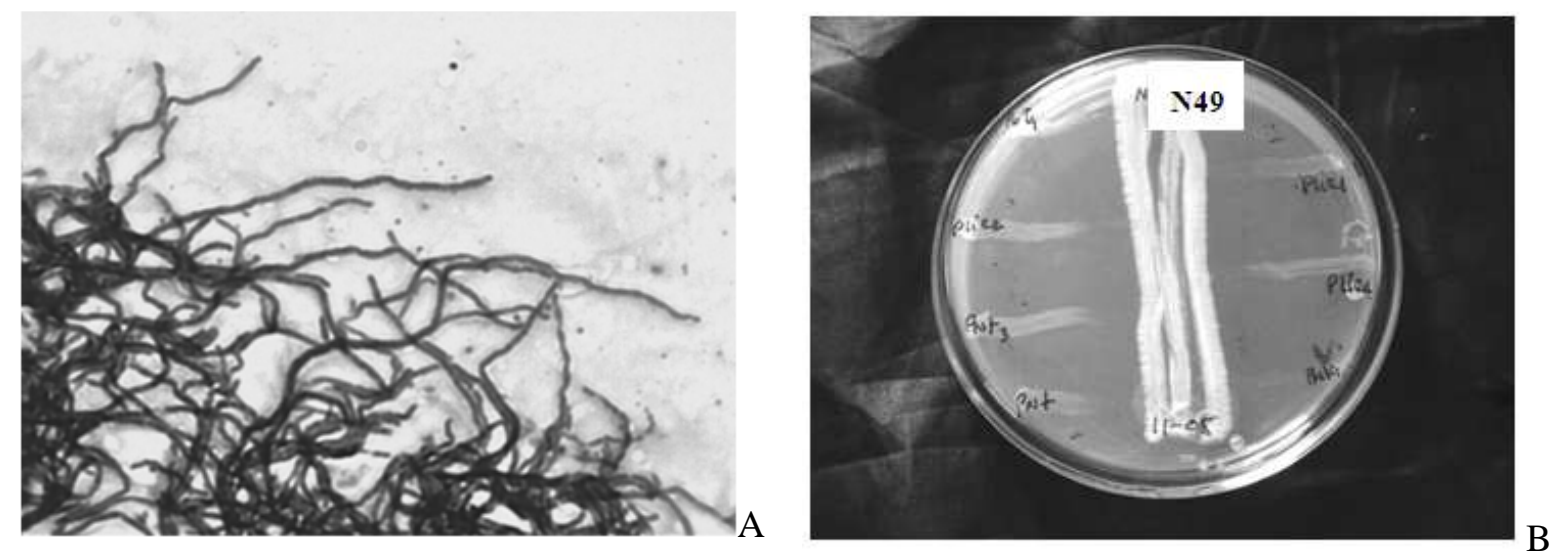

Figure 1 - (A) Microscopic view of Streptomyces sp. isolate N41 (100x) showing long aerial hyphae, after Gram staining. (B) Antagonistic activity of Streptomyces sp. isolate N49 against different fish pathogenic Aeromonas sp. isolates.

Table 4 - Antagonistic activity of Streptomyces sp. isolates against fish and human pathogenic bacteria.

\begin{tabular}{|c|c|c|c|c|c|c|}
\hline \multirow{3}{*}{$\begin{array}{c}\text { Isolates } \\
\text { Name }\end{array}$} & \multicolumn{6}{|c|}{ Test microorganisms with their percentage $(\%)$ of growth inhibition } \\
\hline & \multicolumn{3}{|c|}{ Fish pathogen } & \multicolumn{3}{|c|}{ Human pathogen } \\
\hline & Aeromonas & Pseudomonas & Edwardsiella & Klebsiella & Salmonella & Streptococcus \\
\hline $\mathrm{N} 21$ & 60 & 80 & 70 & 70 & 50 & 60 \\
\hline $\mathrm{N} 23$ & 60 & 60 & 70 & 40 & 60 & 60 \\
\hline $\mathrm{N} 24$ & 80 & 80 & 100 & 90 & 90 & 80 \\
\hline N26 & 80 & 80 & 80 & 100 & 100 & 80 \\
\hline $\mathrm{N} 28$ & 80 & 80 & 90 & 80 & 90 & 90 \\
\hline N47 & 80 & 90 & 80 & 90 & 100 & 80 \\
\hline N49 & 100 & 90 & 90 & 50 & 60 & 60 \\
\hline
\end{tabular}

Various microorganisms have survived for thousands of years by their ability to adapt against antimicrobial drugs and this process enables some bacteria to develop resistance to certain antibiotics, rendering the antibiotics ineffective. As a result, most of the bacteria resistant to multiple antibiotics, causing a crucial threat for the treatment of diseases of human and animals (Bennett 2008). The increasing frequency of multidrug resistant pathogenic bacteria in recent years has created an urgent demand in the pharmaceutical industry for screening of new antibiotics (George 2010; Foysal et al. 2011; Sharmeen et al. 2012; Fuad et al. 2012). The results of present study showed that broad spectrum antibiotic could be developed from the isolates N24, N26, N28 and N47, which could be effective against several human and fish diseases. The isolate N49 could be used as a better source to reduce the prevalence of fish disease.

\section{CONCLUSION}

Soil samples from two different parts of Bangladesh were evaluated for isolating potent Streptomyces sp strains. Results showed that these soils could be good source for isolating antibiotic producing Streptomyces but more studies should 
be carried out to find out valuable antibiotic producing bacteria. Further investigation is also necessary to purify the active novel metabolites from these isolates.

\section{REFERENCES}

Arifuzzaman M, Khatun MR, Rahman H. Isolation and screening of actinomycetes from Sundarbans soil for antibacterial activity. African J Biotechnol. 2010; 9(29): 4615-4619.

Atlas RM. Hand Book of Microbiological Media. 2nd ed. CRC Press Inc. 1997; 595: 1313-1560.

Bennett PM. Plasmid encoded antibiotic resistance: acquisition and transfer of antibiotic resistance genes in bacteria. British J Pharmacol. 2008; 153 (1): 347357.

Berd D. Laboratory Identification of Clinically Important Aerobic Actinomycetes. Appl Microbiol. 1973; 25(4): 665-681.

Bergey DH and John GH. Bergey'sManual of Determinative Biology, Chapter: 4, 9th Edition, William and Wilkins. 1994;181-186.

Ceylan O, Okmen G, Ugur A. Isolation of soil Streptomyces as source antibiotics active against antibiotic-resistant bacteria. EurAsia J BioSci. 2008; 2: 73-82.

Challis GL, Hopwood DA. Synergy and contingency as driving forces for the evolution of multiple secondary metabolite production by Streptomyces species. Proc Natl Acad Sci. 2003; 100 (2):14555-14561.

Dancer SJ. How antibiotics can make us sick: the less obvious adverse effects of antimicrobial chemotherapy. 2004; Lancet Infect Dis. 611-619.

Foysal MJ, Rahman MM , Alam M. Antibiotic sensitivity and In vitro antimicrobial activity of plant extracts to Pseudomonas fluorescens isolates collected from diseased fish. Int J Nat Sci 2011; 1(4): 82-88.

Fuad MMH, Ferdowsy H, Hossain MN, Foysal MJ, Rahman MM. In-vitro Antibacterial Activity of Common Antibiotics and Herb Extracts to Clinical Isolates of Escherichia coli Collected from UTI Patient. Int J Res Pharm Biomed Sci. 2012; 3(2): 987982.

George M, George G, Hatha AAM. Diversity and antibacterial activity of actinomycetes from wetland soil. The South Paci J Nat App Sci. 2010; 28: 52-57.

Gupte M, Kulkarni P, Ganguli BN. Antifungal antibiotics. Appl Microbiol Biotechnol. 2002; 58: 4657.
Kavitha A, Vijayalakshmi M, Sudhakar P, Narasimha G. Screening of Actinomycete strains for the production of antifungal metabolites. African $J$ Microbiol Res. 2010; 4 (1): 027-032.

Kieser T, Bibb MJ, Buttner MJ, Chater KF, Hopwood DA. Practical Streptomyces Genetics. 2nd ed. Norwich, England: John Innes Foundation. 2000.

Korn-Wendisch F, Kutzner HJ. The family Streptomycetaceae. In: Balows A, Truper HG, Dworkin M, Harder W, Schleifer KH (Editors). The Prokaryote. A Handbook on the Biology of Bacteria: Ecophysiology, Isolation, Identification, Application. $2^{\text {nd }}$ ed. Vol 1. New York: Springer-Verlag. 1992; $p$ 921-995.

Küster E, Williams ST. Selection of Media for Isolation of Streptomycete. Nature. 1964; 202: 928-929.

Lemos ML, Toranzo AE, Barja JL. Antibiotic activity of epiphytic bacteria isolated from intertidal seaweeds. Microbial Ecol 1985; 11: 149-163.

Rahman MA, Islam MZ,Ul-Islam MA. Antibacterial Activities of Actinomycete Isolates Collected from Soils of Rajshahi, Bangladesh. Biotechnol Res Int. 2011; 1-6.

Santos ÉRD, Teles ZNS, Campos NM, Souza DAJ, Bispo ASR, Nascimento RP. Production of $\alpha$ Amylase from Streptomyces sp. SLBA-08Strain Using Agro-Industrial By-Products. Braz Arch Biol Technol. 2012; 55 (5): 793-800.

Sharmeen R, Hossain MN, Rahman MM, Foysal MJ, Miah MF. In-vitro antibacterial activity of herbal aqueous extract against multi-drug resistant Klebsiella sp. isolated from human clinical samples. Int Curr Pharm J. 2012;1(6): 133-137.

Shirling EB,Gottlieb D. Methods for characterization of Streptomyces species. Int J Syst Evol Microbiol. 1966; 16 (3) 313-340.

Takahashi YO, Omura S. Isolation of new actinomycete strains for the screening of new bioactive compounds. J Gen Applied Microbiol. 2003; 49: 141-154.

Valli S, Sugasini SS, Aysha OS, Nirmala P, Kumar VP, Reena A. Antimicrobial potential of Actinomycetes species isolated from marine environment. Asian Pac J Trop Biomed. 2012; 2(6): 469-473.

Williams ST, Goodfellow M, Alderson G, Wellington EMH, Sneath PHA, Sackin MJ. Numerical classification of Streptomyces and related genera. $J$ Gen Microbiol. 1983; 129: 1743-1813.

Received: January 01, 2013; Accepted: November 23, 2013. 